\title{
What does a non-response to induction chemotherapy imply in high-risk medulloblastomas?
}

Jihane Adelon ( $\square$ jihane.adelon@gmail.com )

Institut d'Hematologie et d'Oncologie Pediatrique https://orcid.org/0000-0001-6451-2564

Christelle Dufour

Gustave Roussy Institute: Gustave Roussy

Stéphanie Foulon

Gustave Roussy Institute: Gustave Roussy

Julien Masliah Planchon

Institute Curie: Institut Curie

David Meyronnet

Civil Hospices of Lyon Center for Pathology and Biology East: Hospices Civils de Lyon Centre de pathologie et biologie Est

Franck Bourdeault

Institute Curie: Institut Curie

Gilles Palenzuela

Hôpital Arnaud de Villeneuve: Hopital Arnaud de Villeneuve

Fanny Fouyssac

CHU Nancy: Centre hospitalier regional universitaire de Nancy

Sandra Raimbault

Oscar Lambret Cancer Centre: Centre Oscar Lambret

Emilie De Carli

CHU Angers: Centre Hospitalier Universitaire d'Angers

Sébastien Klein

CHU Besancon: Centre Hospitalier Universitaire de Besancon

Anne Pagnier

Grenoble Alpes University Hospital Centre Couples and Children Section: Centre Hospitalier Universitaire Grenoble Alpes Pole Couple Enfant

Anne-Isabelle Bertozzi

Hôpital des Enfants: Hopital des Enfants

Angélique Rome

CHU Timone: Hopital de la Timone

Audrey David

CHU Saint-Étienne: Centre Hospitalier Universitaire de Saint-Etienne

Sylvie Chabaud

Centre Léon Bérard: Centre Leon Berard

Cécile Faure-Conter

Institut d'Hematologie et d'Oncologie Pediatrique

\section{Research Article}

Keywords: High-risk pediatric medulloblastomas, Stable disease-Progressive disease, High-dose chemotherapy, Survival-Relapse.

Posted Date: March 18th, 2021

DOI: https://doi.org/10.21203/rs.3.rs-315237/v1

License: @ (i) This work is licensed under a Creative Commons Attribution 4.0 International License. Read Full License 


\section{Abstract}

Purpose. Some high-risk medulloblastomas (HR-MB) do not respond to induction chemotherapy, with either post-induction stable (SD) or progressive disease (PD). To date, there is no consensus regarding their optimal management.

Methods. A retrospective, multicentre study of non-responder HR-MB patients treated according to the PNET HR+5 protocol (NCT00936156) between 01/01/2009 and 31/12/2018. After two courses of etoposide and carboplatin induction chemotherapy, patients with SD or PD were analyzed. Based on the clinician's decision, the PNET HR+5 protocol was either pursued with tandem high-dose chemotherapy (HDCT) and craniospinal irradiation (CSI) (continuation group) or it was modified (switched group).

Results. Forty-nine patients were identified. After induction, 37 patients had SD and 12 had PD. The outcomes were significantly better for the SD group: the 5 y PFS and OS were 52\% (95\% confidence interval [95\% Cl] 35-67) and 70\% (95\% Cl 51-83), respectively, in the SD group and 17\% (95\% Cl 3-41) and 13\% (95\% Cl 1-40), respectively, in the PD group ( $p<0.0001)$. The PNET HR+5 strategy was pursued for 3 patients in the PD group, of whom only one survived. In the SD group, it was pursued for 24 patients. The 5 -y PFS and the OS were $78 \%(95 \% \mathrm{Cl} 54-90)$ in the continuation group and $0 \%$ and $56 \%$ (95\% $\mathrm{Cl} 23-79)$, respectively, in the switched group. In the SD group, multivariate analysis revealed that MYC amplification, molecular group 3, and a switched strategy were independent prognostic factors for progression.

Conclusion. Patients with post-induction SD may benefit from HDCT and CSI, whereas improvement of the way patients with early PD are treated will require new therapeutic approaches.

\section{Introduction}

Medulloblastoma (MB) is the most common type of malignant brain tumor in childhood, accounting for $20 \%$ of all brain tumors [1]. MBs are divided into three groups, depending on biological and radiological criteria: low-risk, standard-risk, and high-risk groups. High-risk medulloblastomas (HR-MBs) are defined as M1 to M3 metastatic disease according to the Chang classification [2], and/or (ii) a more than $1.5 \mathrm{~cm}^{2}$ postoperative residual tumor assessed within $48 \mathrm{~h}$ after surgery (R+), and/or (iii) a large-cell/anaplastic histology (LCA MB) according to the 2016 WHO classification [1], and/or (iv) a MYCN or MYC amplification. Various chemotherapy regimens have been developed in a number of different countries and combined with historically used craniospinal irradiation (CSI) with the objective of improving outcomes. These treatments encompass the use of induction chemotherapy followed by CSI [3]; CSI followed by four courses of tandem high-dose chemotherapy (HDCT)[4]; and induction chemotherapy followed by hyperfractionated accelerated CSI followed by either HDCT or maintenance therapy according to the pre-irradiation status [5]. In France, the national PNET HR+5 phase II trial, launched in 2009, recruited HR-MB patients who were over 5 years of age. After removal of the primary tumor, the therapy consisted of two courses of induction chemotherapy followed by tumor reassessment and tandem thiotepa-based HDCT, CSI, and maintenance therapy. Details of this strategy are provided in the Methods section. As this strategy yielded encouraging results [6], the same strategy was applied after the trial had closed for HR-MB patients of any age, with dose-adapted radiotherapy for children under five years of age. Nevertheless, a minor proportion of the HR-MBs did not respond to induction chemotherapy, with either stable (SD) or progressive disease (PD). As HDCT relies on the concept of chemosensitivity, the non-response to induction chemotherapy calls into question the indication for HDCT, and there is hitherto no consensus as to how such non-responder HR-MBs should be managed. Therapeutic strategies for relapsing or refractory HRMBs rely mainly on temozolomide-based regimens such as topotecan-temozolomide (TOTEM)[7] or temozolomide-irinotecan (TEMIRI) combinations [8]. The modified "Saint Jude" strategy consisting of CSI followed by four cycles of cisplatin, vincristine, and cyclophosphamide HDCT [4] is also occasionally used in a salvage setting.

Should HR-MBs that do not respond to induction chemotherapy be considered refractory disease and should the initially planned strategy be changed accordingly? To address these questions, the aim of this study was to describe the outcomes of patients with HR-MBs that did not respond to induction chemotherapy and to evaluate the impact of the post-induction status, therapeutic strategies, and tumor biology on the outcomes.

\section{Patients And Methods}

A retrospective, multicentre, French study was performed, aiming to collect all cases of patients with HR-MB treated between January $1^{\text {st }}, 2009$ and December $31^{\text {st }}, 2018$ according to the PNET HR+5 strategy and who did not respond to induction chemotherapy.

\section{Population.}

Patients aged 0 to 19 years with a newly diagnosed HR-MB treated with the PNET HR+5 strategy and (further referred to as "non-responder" HR-MBs) were eligible for enrollment. The patients could have been treated within the PNET HR+5 protocol (NCT00936156) ("protocolar" patients)[6] or according to this strategy but outside the protocol ("non-protocolar" patients). The protocolar patients were retrieved from the PNET HR+5 protocol database whereas the nonprotocolar patients were identified after interrogation of each neurooncologist in the SFCE (Société Française des Cancers de l'Enfant) centers.

\section{Treatment}

Between January $19^{\text {th }}, 2009$ and February $28^{\text {th }}, 2012$, the French PNET HR+5 protocol recruited HR-MB patients who were between 5 and 19 years of age. After primary tumor biopsy or resection, the therapy consisted of two courses of induction chemotherapy with etoposide (100 mg/m²/day for 5 days) and carboplatin (160 mg/m²/day for 5 days) (EC) with a 3-week interval, followed by tumor resection if indicated. Except in case of progression, the intensification consisted of tandem HDCT with two courses of high-dose thiotepa (HD-TTP) (200 mg/m²/ day, for 3 days) spaced by three or four weeks, followed by autologous stem cell transplantation (ASCT). Thereafter, CSI was scheduled to start no more than 45 days after the last ASCT. Details of the treatment 
protocol are described in Dufour et al, 2020 [6]. The protocol included centralized pathological review, centralized radiological review for assessment of the treatment response, and real-time radiotherapy quality control.

\section{Biological data}

Molecular grouping was obtained by NanoString [9] or methylation profiling [10].

\section{Assessment of the response to treatment.}

The response to induction chemotherapy was evaluated on the post-induction chemotherapy MRI, which was compared with the pretherapeutic MRI and assessed using the Response Assessment in Neuro-Oncology (RANO) criteria for measurable lesions [11] and non-measurable disease [12]. When initially positive, the post-induction CSF cytology was also considered for the response assessment [13]. A complete response (CR) was defined as the disappearance of all radiologically discernible tumors and a negative CSF. A partial response (PR) was defined as at least a $50 \%$ decrease in tumor size measured by the sum of the products of the maximum perpendicular diameters of all of the measurable lesions and a decrease in the non-measurable lesions and a negative CSF cytology. Progressive disease (PD) was classified as at least a $25 \%$ increase in tumor size measured by the sum of the products of the maximum perpendicular diameters of all of the measurable lesions, and/or an increase in the non-measurable lesions and/or a positive CSF cytology when it had previously been negative. "PD-CSF-only" applied to the patients with either radiologic CR, PR, or SD but a post-induction positive CSF cytology when it had previously been negative. Stable disease (SD) was defined as a condition where neither the CR, PR, or PD criteria were reached. "SD-CSF-only" applied to the patients with either radiologic CR or PR but a positive CSF cytology when it had previously been positive.

\section{Statistical analysis.}

The date of the first surgery leading to a histological diagnosis was retained as the date of the diagnosis. Survival curves for overall survival (OS, the time from diagnosis to death from any cause or censured to the date of the most recent follow-up) and progression-free survival (PFS, the time from diagnosis to disease progression or death from any cause or censored to the date of the most recent follow-up) were generated using the Kaplan-Meier method and compared between the different groups using the log-rank test. Survival rates at 5 years were extracted with their $95 \%$ confidence interval ( $95 \% \mathrm{Cl}$ ) from Kaplan-Meier estimations. The median follow-up was estimated using the inverse Kaplan-Meier method. Fisher's exact tests and Wilcoxon non-parametric tests were used to study the impact of prognostic factor: histology (LCA versus CMB/DMB/NOS), molecular subgroup (group 3 versus other groups, MYC/MYCN amplification (yes versus no), postoperative residue ( $\mathrm{R}+$ versus $\mathrm{R} 0 / \mathrm{R}-$ ), Chang stage (M2/M3 versus M0/M1), and baseline CSF (positive versus negative). Multivariate analyses were performed by using Cox multivariate regression models with backward stepwise selection. The significance level was set to a p-value $=0.05$. SAS version 9.4 software was used for all of the statistical analyses (SAS Institute Inc., Cary, NC, USA).

\section{Ethical consideration}

The study was conducted according to the French Reference Methodology MR-004 (Commission Nationale Informatique et Libertés CNIL reference number 2217201v0).

\section{Results}

\section{1/Population}

The selection of the patients is shown in Flowchart 1a (Fig. 1). Sixty-one children were identified in 14 French SFCE centers. Of these, 12 patients were excluded for the following reasons: non-medulloblastoma histology $(n=1)$, non-PNET HR+5 strategy $(n=5)$, lack of high-risk features $(n=1)$, diagnosis after the eligible period $(n=1)$, partial response after review $(n=3)$, and non-assessable response $(n=1)$

Forty-nine patients were retained for the analysis, including 19 protocolar and 30 non-protocolar patients. Table 1 provides the main characteristics of the patients. The median age at diagnosis was 7.34 years (range 2.00-18.6). The protocolar group and the non-protocolar group were not statistically different in terms of the repartition of the following high-risk features ( $\mathrm{R}+$, LCA histology, MYC/MYCN amplification, positive baseline CSF, M2-M3 Chang stage, and group 3). All but one of the patients received induction chemotherapy with two courses of etoposide and carboplatin. One patient received a third course to allow for peripheral stem cell harvesting. The post-induction status was SD for 37 and PD for 12 patients.

\section{2/ Characteristics, post-induction treatments, and outcomes}

\section{- The SD group $(n=37)$}

The main characteristics of the patients with post-induction SD are presented in Table $2 a$ for the non-protocolar patients ( $\mathrm{n}=21)$ and Table $2 \mathrm{~b}$ for the protocolar patients ( $n=16)$. Thirty-five (95\%) patients had M2/M3 metastatic disease, 19 (51\%) were R+, 16 (46\%) had an initial positive CSF cytology, 4 (11\%) had an LCA histology, 13 (42\%) were group 3, and 6 (17\%) had MYC/MYCNamplification. Twenty-seven (73\%) had more than one high-risk feature.

After induction chemotherapy, 33 were considered to have SD based on imaging assessment including 8 who had persistent positive CSF. Seventeen patients were assessable for a response both on the primitive tumor and the metastases, three of whom had a dissociated response with either a partial response on the primitive tumor and SD on the metastases $(n=2)$ or the reverse $(n=1)$. Four were SD-CSF-only.

Immediately after the induction chemotherapy, 9 (24\%) patients had a second-look surgery, which was complete in 3 cases. The post-induction treatments are described in Flowchart 1b (Fig. 1). Twenty-four (65\%) patients pursued the PNET HR+5 strategy with HD-TTP. Nineteen (79\%) patients received the two 
intended courses of HD-TTP before irradiation, while $5(21 \%)$ patients received only one course due to either long-lasting thrombopenia ( $\mathrm{n}=1)$ or due to the response to the first HD-TTP being deemed insufficient $(n=4)$. Of these 5 patients, 1 received four courses of TEMIRI before CSI, whereas another received a salvage course of TOTEM but rapidly died of progressive disease without being irradiated. In total, 23/24 patients received CSI, with a median interval from the time of diagnosis of 147 days (range 116-193 days). Fifteen (62\%) of these 24 patients received a temozolomide-based maintenance therapy, either alone $(n=14)$ or as a metronomic in association with oral etoposide, cyclophosphamide, celecoxib, and isotretinoin [14] ( $n=1)$. The remaining 9 did not receive this due to hematologic toxicity $(n=6)$, refusal $(n=2)$, or death $(n=1)$. With a median follow-up of 80 months $(5.7-121.1), 19(79 \%)$ of these 24 patients were still alive. Seventeen had a continuous complete response (CCR), including the four who were SD-CSF-only, two were alive with disease (AWD), and five had died of the disease.

For the other 13 children (all in the non-protocolar group), the initial treatment was switched based on the physician's decision, with either second-line standard-dose chemotherapy (SDCT) alone $(n=1), \operatorname{CSI}(n=3$,$) , or both treatments (n=9)$. The SDCT administered were cyclophosphamide $(n=2)$, TOTEM $(n=4)$, and TEMIRI $(n=4)$. After the CSI, 6 patients out of 12 received delayed HDCT according to the modified Saint Jude strategy. With a median follow-up of 33.4 months (4.0-80.7), 7 (54\%) of these 13 patients were still alive. One was in CCR, 6 were AWD, and 6 had died of the disease.

\section{- The PD group $(n=12)$}

The main characteristics and the outcomes of the patients with post-induction PD are presented in Table 2c. Three were protocolar and 9 were non-protocolar patients. Eight (66\%) had M2/M3 metastatic disease, 5 (42\%) were R+, $6(50 \%)$ had an initial positive CSF, 6 (50\%) had an LCA histology, 5 of the 7 patients with a conclusive NanoString analysis were in group 3, and 5 (42\%) had MYC/MYCN amplification. Eight (66\%) had more than one high-risk feature.

After induction chemotherapy: 10 had PD based on imaging, of whom 2 also had newly positive CSF, and 4 had persistent positive CSF. Two were PD-CSFonly. The post-induction treatments are indicated in Flowchart 1c (Fig. 1).

Immediately after the induction therapy, only one patient had a second-look surgery, which led to subtotal resection, and one patient died early on after the second course of EC without any further treatment.

Three pursued the PNET HR+5 strategy, but only one completed the full protocol and they were in CCR after 85 months of follow-up. Of the remaining two patients, one relapsed early after the second HD-TTP, they did not receive the CSI and they died of the disease soon after one course of TEMIRI. The second patient had persistent PD after one course of HD-TTP, and they received a salvage CSI followed by the modified Saint Jude strategy. This patient died of distant relapse 14 months after their diagnosis.

For eight children, the initially intended treatment changed due to post-induction progression, with either second-line SDCT alone ( $n=5)$, or salvage CSI ( $\mathrm{n}=2$ ), or both $(n=1)$. The SDCT administered were cyclophosphamide $(n=1)$ TOTEM $(n=3)$, and TEMIRI $(n=2)$. Two patients received a post-radiation temozolomidebased regimen.

With a median follow-up of 7.5 months (range 2.4-84.8), among the 12 patients of the PD group, 2 were still alive and in CCR (16\%) while the ten other patients had died of the disease. The two PD-CSF-only patients survived: one was treated with the full PNET HR+5 protocol whereas the other received no HDCT but a CSI followed by temozolomide maintenance.

\section{3/ Prognostic factors}

\section{Prognostic factors in the entire cohort}

In univariate analysis, LCA histology $(p=0.007, p<0.0001)$, positive baseline CSF $(p=0.0125, p=0.0209)$, and group $3(p=0.0045, p=0.0003)$ were statistically significant adverse prognostic factors of both PFS and OS, respectively. MYC/MYCN amplification was a negative predictor for OS ( $\mathrm{p}=0.0063$ ) but not PFS $(p=0.06)$.

There was a significant impact of the post-induction chemotherapy status on the outcomes, as shown in Figures 2a and 2b: the 5-y PFS and OS were 52\% (95\% Cl 35-67) and 70\% (95\% Cl 51-83), respectively, in the SD group and 17\% (95\% Cl 3-41) and 13\% (95\% Cl 1-40), respectively, in the PD group ( $\mathrm{p}<0.0001$ for both) (Fig. 2a and 2b).

Group 3 molecular subgroup ( $p=0.22)$, the presence of $M Y C / M Y C N$ amplification $(p=0.11), R+$ status $(p=0.74)$, and a positive baseline $C S F(p=1.0)$ were not associated with the post-induction status (SD versus PD), while an LCA histology led to a significantly increased risk of PD (OR=7.77 (95\% Cl 1.3-50.7)), $\mathrm{p}=0.008)$.

\section{Prognostic factors in the PD group}

We did not identify a successful strategy in the PD group. Two of the three patients receiving HDCT died of the disease. There appeared to be no benefit of $\mathrm{HDCT}$, although it could not be properly assessed due to the small number of patients.

\section{Prognostic factors in the SD group}

Of the 37 patients in the SD group, continuation of the PNET HR+5 strategy led to a statistically better 5-y PFS (78\% versus $0 \%)(p<0.001)$ and a trend of a better 5 -y OS in 78\% (95\% Cl 54-90) versus 56\% (95\% Cl 23-79), respectively, $(\mathrm{p}=0.0618)$. There was not a statistical difference in the PFS of the protocolar patients versus the non-protocolar patients who pursued the PNET HR+5 strategy (5-y PFS $81 \%$ ( $95 \%$ Cl 52-94) versus 75\% (95\% Cl 32-93), respectively, 
$(p=0.52)$ (Fig. 3a and 3b). Similarly, we found no statistical differences in the outcomes of the patients with a dissociated response compared to those with SD both on the primitive tumor and the metastases $(p=0.5735)$.

The univariate and the multivariate analyses are presented in Tables $3 \mathrm{a}$ and $3 \mathrm{~b}$. The multivariate analysis indicated that $M Y C / M Y C N$ amplification and group 3 were independent predictors of shorter OS, whereas a switched strategy, MYC/MYCN amplification, and group 3 were independent factors for shorter progression.

\section{Discussion}

In this series of 49 children with HR-MB who had all been treated with EC induction chemotherapy, the post-induction status had an impact on the prognosis, with significantly better outcomes for the patients in the SD group compared to those in the PD group. We also obtained evidence that patients in the SD group benefit from continuation of the PNET HR+5, with HDCT and CSI.

The literature reports a variable 14-37\% rate of non-responder HR-MBs after various types of induction chemotherapy [3,15-18], including intensified therapies [19]. The effectiveness of EC combination was assessed in a series of 26 children with evaluable MBs. The objective response rate (ORR) (defined as the proportion of patients with either a CR or a PR) after two courses of treatment was $72 \% \pm 10$ [20]. In the PNET HR+5 protocol, after the two courses of EC, 16 (31\%) patients had SD and 3 (6\%) had PD. All of these were included in the present series. The response rate was 62.8\% [21]. The prognostic impact of the response to induction chemotherapy of HR-MBs on the final outcome is still a matter of debate. For some authors, it represented a major prognostic factor $[3,5,13,16,17,19]$ whereas for others it did not $[15,21,22]$.

Regarding histological and biological factors, the proportion of LCA-HR-MBs (20\%) in the current series is in the range reported in studies of newly-diagnosed HR-MBs (4\%-23\%) $[4,5,18,19,21]$. The percentage of group 3 (37\%) was slightly higher than what has been reported previously $(25 \%)[4,19,21,23]$, but it is not possible to assess whether this is due to missing data or to the context of non-responder HR-MBs that involved more severe conditions. As previously reported $[4,19,21,23]$, the current series confirms the detrimental impact of an LCA histology, MYC/MYCNamplification, and subgroup 3 on the outcome. In univariate analysis, we also found that LCA HR-MBs had an increased risk of having PD rather than SD.

Regarding the disease stage, few patients were only metastatic on the CSF (Chang stage M1). Consequently, we are not able to add to the debate whether patients with Chang M1 HR-MBs have [15,16,24] or do not have [13] a better prognosis compared to Chang M2-M3 HR-MBs. Nevertheless, the CSF status had a prognostic impact at different time points in our study. A positive baseline CSF was negatively correlated to the outcome. Its relevance after EC induction is less clear. While no recurrences or deaths were observed among the patients with SD or PD based on CSF only, SD or PD based on imaging had a significantly adverse effect on the outcomes. If reproduced in a larger prospective cohort, this might be reason to question the therapeutic relevance of performing a postinduction lumbar puncture.

Patients with PD following induction chemotherapy have a dismal prognosis [3]. Performing HDCT in the setting of PD is not supported by our results, with the possible exception of patients with PD on the CSF only. Data regarding this latter category are lacking in the literature and this warrants further investigation. New therapeutics will be required to improve the way the other patients with post-induction PD are treated.

For patients with SD, the analysis and comparison with the results in the literature are more complex for several reasons. Firstly, the definition of SD can vary from one series to another. For example, some series consider the status of the CSF $[4,5,13,15,18,25]$ whereas other do not $[16,17]$. Secondly, patients with SD have been admixed with those with CR and PR in some series [3] or analyzed with those with PD in other series [5,13,16,17,19]. Lastly, patients with SD represent a minority in the series to date reporting a response to induction chemotherapy. In the current series, continuation of the PNET HR+5 protocol with tandem HD-TTP and CSI provided a better PFS than the switched strategy. Interestingly, it led to similar outcomes (the 5-y PFS and OS were 78\% (95\% CI 5490) and $78 \%$ (95\% Cl 55-90), respectively) compared to the 32 patients with responding HR-MBs included in the PNETHR+5 trial (for whom the 5-y PFS and OS were $81.1 \%(95 \% \mathrm{Cl} 64.5-91.1)$ and $81 \%(95 \% \mathrm{Cl} 64.3-91)$, respectively [21]). These results contradict the generally accepted necessity of having a minimal tumor burden prior to HDCT $[17,26]$ or at least evidence of chemosensitivity proven by a decrease in tumor size. Indeed, because the treating physicians considered the response insufficient to allow for PNET HR+5 continuation with HDCT, two-thirds of the non-protocolar patients received a switched therapy, which had a detrimental impact on their outcomes.

Our study is limited by its non-randomized retrospective nature. However, its design allows for comparison of patients treated with the same induction either within a protocol or in "real life" conditions, and -to our knowledge- it is the only series to date to specifically focus on non-responder HR MBs.

\section{Conclusion}

In this series focused on non-responder HR-MBs, patients with early PD had a dismal prognosis, with the possible exception of those with CSF-only progression. This group did not appear to derive any benefit from intensification, and new therapeutic approaches are needed in this setting. On the other hand, the patients with post-induction SD and treated with HDCT and CSI reached the outcomes published for responder tumors and they should hence probably be counted as having achieved a response.

\section{Declarations}

Funding: The authors did not receive support from any organization for the submitted work.

Conflicts of interest: The authors have no relevant financial or non-financial interests to disclose. 
Consent to participate: Written consent was obtained from the parents/guardians of living patients by a letter of non-opposition to study participation that was sent and in which the aims of the study were described and the guarantee that the patient's personal details would remain anonymous was affirmed.

Ethics approval: Ethics approval was waived by the local Ethics Committee of the Centre Léon Bérard in light of the retrospective nature of the study, and all of the procedures that were performed were part of the routine care. The study was conducted according to the French Reference Methodology MR-004 (Commission Nationale Informatique et Libertés CNIL reference number 2217201v0).

Data availability: The datasets generated during and/or analysed during the current study are available from the corresponding author on reasonable request.

\section{Author contributions}

Conceptualization, methodology, data analysis and interpretation, writing-original draft, review, editing: J. Adelon and C. Faure-Conter

Statistical analysis, data interpretation: S. Chabaud.

Data collection, writing, review: all authors.

\section{Acknowledgments}

We would like to thank Lila Saidoun, Marianne Roumy, Isabelle Couteau, Cécile Dumesnil-de Maricourt, Céline Icher, and Yaelle Ouldbey for their assistance with various aspects of this study.

\section{References}

1. Louis DN, Perry A, Reifenberger G, et al. The 2016 World Health Organization Classification of Tumors of the Central Nervous System: a summary. Acta Neuropathol (Berl). 2016;131(6):803-820. doi:10.1007/s00401-016-1545-1

2. Chang $\mathrm{CH}$, Housepian EM, Herbert C. An operative staging system and a megavoltage radiotherapeutic technic for cerebellar medulloblastomas. Radiology. 1969;93(6):1351-1359. doi:10.1148/93.6.1351

3. Taylor RE, Bailey CC, Robinson KJ, et al. Outcome for patients with metastatic (M2-3) medulloblastoma treated with SIOP/UKCCSG PNET-3 chemotherapy. Eur J Cancer Oxf Engl 1990. 2005;41(5):727-734. doi:10.1016/j.ejca.2004.12.017

4. Gajjar A, Chintagumpala M, Ashley D, et al. Risk-adapted craniospinal radiotherapy followed by high-dose chemotherapy and stem-cell rescue in children with newly diagnosed medulloblastoma (St Jude Medulloblastoma-96): long-term results from a prospective, multicentre trial. Lancet Oncol. 2006;7(10):813-820. doi:10.1016/S1470-2045(06)70867-1

5. Gandola L, Massimino M, Cefalo G, et al. Hyperfractionated accelerated radiotherapy in the Milan strategy for metastatic medulloblastoma. J Clin Oncol Off J Am Soc Clin Oncol. 2009;27(4):566-571. doi:10.1200/JC0.2008.18.4176

6. Dufour C, Foulon S, Geoffray A, et al. Prognostic relevance of clinical and molecular risk factors in children with high-risk medulloblastoma treated in the phase 2 trial PNET HR+5. Neuro-Oncol. Published online December 30, 2020. doi:10.1093/neuonc/noaa301

7. Le Teuff G, Castaneda-Heredia A, Dufour C, et al. Phase II study of temozolomide and topotecan (TOTEM) in children with relapsed or refractory extracranial and central nervous system tumors including medulloblastoma with post hoc Bayesian analysis: A European ITCC study. Pediatr Blood Cancer. 2020;67(1):e28032. doi:10.1002/pbc.28032

8. Grill J, Geoerger B, Gesner L, et al. Phase II study of irinotecan in combination with temozolomide (TEMIRI) in children with recurrent or refractory medulloblastoma: a joint ITCC and SIOPE brain tumor study. Neuro-Oncol. 2013;15(9):1236-1243. doi:10.1093/neuonc/not097

9. Northcott PA, Shih DJH, Remke M, et al. Rapid, reliable, and reproducible molecular sub-grouping of clinical medulloblastoma samples. Acta Neuropathol (Berl). 2012;123(4):615-626. doi:10.1007/s00401-011-0899-7

10. Schwalbe EC, Williamson D, Lindsey JC, et al. DNA methylation profiling of medulloblastoma allows robust subclassification and improved outcome prediction using formalin-fixed biopsies. Acta Neuropathol (Berl). 2013;125(3):359-371. doi:10.1007/s00401-012-1077-2

11. Chukwueke UN, Wen PY. Use of the Response Assessment in Neuro-Oncology (RANO) criteria in clinical trials and clinical practice. CNS Oncol. 2019;8(1). doi:10.2217/cns-2018-0007

12. Chamberlain M, Junck L, Brandsma D, et al. Leptomeningeal metastases: a RANO proposal for response criteria. Neuro-Oncol. 2017;19(4):484-492. doi:10.1093/neuonc/now183

13. Dufour C, Beaugrand A, Pizer B, et al. Metastatic Medulloblastoma in Childhood: Chang's Classification Revisited. Int J Surg Oncol. $2012 ; 2012: 245385$. doi:10.1155/2012/245385

14. Choi LMR, Rood B, Kamani N, et al. Feasibility of metronomic maintenance chemotherapy following high-dose chemotherapy for malignant central nervous system tumors. Pediatr Blood Cancer. 2008;50(5):970-975. doi:10.1002/pbc.21381

15. Verlooy J, Mosseri V, Bracard S, et al. Treatment of high risk medulloblastomas in children above the age of 3 years: a SFOP study. Eur J Cancer Oxf Engl 1990. 2006;42(17):3004-3014. doi:10.1016/j.ejca.2006.02.026

16. Kortmann RD, Kühl J, Timmermann B, et al. Postoperative neoadjuvant chemotherapy before radiotherapy as compared to immediate radiotherapy followed by maintenance chemotherapy in the treatment of medulloblastoma in childhood: results of the German prospective randomized trial HIT ' 91 . Int J Radiat Oncol Biol Phys. 2000;46(2):269-279. doi:10.1016/s0360-3016(99)00369-7 
17. Sung KW, Yoo KH, Cho EJ, et al. High-dose chemotherapy and autologous stem cell rescue in children with newly diagnosed high-risk or relapsed medulloblastoma or supratentorial primitive neuroectodermal tumor. Pediatr Blood Cancer. 2007;48(4):408-415. doi:10.1002/pbc.21064

18. Dufour $C$, Kieffer $V$, Varlet $P$, et al. Tandem high-dose chemotherapy and autologous stem cell rescue in children with newly diagnosed high-risk medulloblastoma or supratentorial primitive neuro-ectodermic tumors. Pediatr Blood Cancer. 2014;61(8):1398-1402. doi:10.1002/pbc.25009

19. von Bueren AO, Kortmann R-D, von Hoff K, et al. Treatment of Children and Adolescents With Metastatic Medulloblastoma and Prognostic Relevance of Clinical and Biologic Parameters. J Clin Oncol Off J Am Soc Clin Oncol. 2016;34(34):4151-4160. doi:10.1200/JC0.2016.67.2428

20. Gentet JC, Doz F, Bouffet E, et al. Carboplatin and VP 16 in medulloblastoma: A phase Il study of the French Society of Pediatric Oncology (sfop). Med Pediatr Oncol. 1994;23(5):422-427. doi:10.1002/mpo.2950230506

21. Dufour C, Foulon S, Geoffray A, Masliah-Planchon J, Faure-Conter C. Prognostic relevance of clinical and molecular risk factors in children with high-risk medulloblastoma treated in the phase 2 trial PNET HR+5. Neuro-Oncology.

22. Tarbell NJ, Friedman H, Polkinghorn WR, et al. High-risk medulloblastoma: a pediatric oncology group randomized trial of chemotherapy before or after radiation therapy (POG 9031). J Clin Oncol Off J Am Soc Clin Oncol. 2013;31(23):2936-2941. doi:10.1200/JC0.2012.43.9984

23. Kool M, Korshunov A, Remke M, et al. Molecular subgroups of medulloblastoma: an international meta-analysis of transcriptome, genetic aberrations, and clinical data of WNT, SHH, Group 3, and Group 4 medulloblastomas. Acta Neuropathol (Berl). 2012;123(4):473-484. doi:10.1007/s00401-012-0958-8

24. Zeltzer PM, Boyett JM, Finlay JL, et al. Metastasis stage, adjuvant treatment, and residual tumor are prognostic factors for medulloblastoma in children: conclusions from the Children's Cancer Group 921 randomized phase III study. J Clin Oncol Off J Am Soc Clin Oncol. 1999;17(3):832-845. doi:10.1200/JC0.1999.17.3.832

25. Osorio DS, Dunkel IJ, Cervone KA, et al. Tandem thiotepa with autologous hematopoietic cell rescue in patients with recurrent, refractory, or poor prognosis solid tumor malignancies. Pediatr Blood Cancer. 2018;65(1). doi:10.1002/pbc.26776

26. Pérez-Martínez A, Lassaletta A, González-Vicent M, Sevilla J, Díaz MA, Madero L. High-dose chemotherapy with autologous stem cell rescue for children with high risk and recurrent medulloblastoma and supratentorial primitive neuroectodermal tumors. J Neurooncol. 2005;71(1):33-38. doi:10.1007/s11060004-4527-4

\section{Tables}

Table 1 Characteristics at diagnosis for the protocolar and the non-protocolar patients.

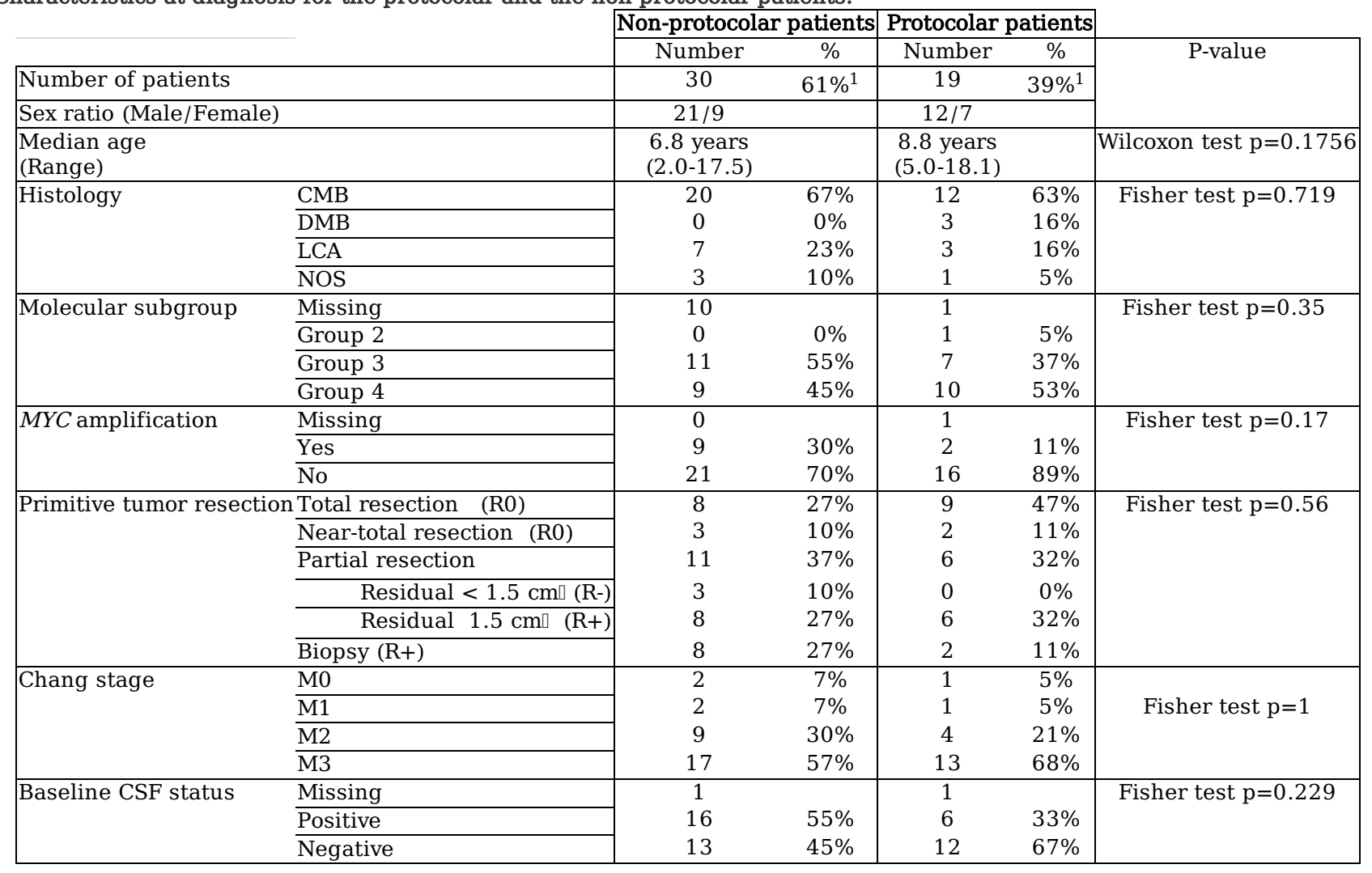

$\%^{1}$ : \% protocolar/non-protocolar among the entire cohort

R0: absence of postoperative residue, R+: postoperative residue $1.5 \mathrm{~cm}^{2}$; R-: postoperative residue $<1.5 \mathrm{~cm}^{2}$;

CMB: classical MB; LCA: large-cell anaplastic MB; DMB: desmoplastic MB; NOS: no other specified; CSF: cerebrospinal fluid

Table 2 Characteristics of the non-protocolar (2a) and the protocolar ( $2 \mathrm{~b})$ patients with post-etoposide-carboplatin induction stable disease and of the patients with post-etoposide-carboplatin induction progressive disease (2c). 


\begin{tabular}{|c|c|c|c|c|c|c|c|c|c|c|c|c|c|c|}
\hline Num & $\begin{array}{c}\text { Gender/ } \\
\text { Age (y) }\end{array}$ & $\begin{array}{c}\text { Initial } \\
\text { Surgery } \\
(\mathbb{R} \\
\text { status) }\end{array}$ & Histology & $\begin{array}{l}\text { MB } \\
\text { group }\end{array}$ & $\begin{array}{l}\text { MYCA } \\
\text { MYCNA }\end{array}$ & Chang & $\begin{array}{c}\text { Baseline } \\
\text { CSF }\end{array}$ & $\begin{array}{l}\text { Post- } \\
\text { EC } \\
\text { CSF }\end{array}$ & $\begin{array}{c}\mathrm{PT} \\
\text { response } \\
\text { to } \mathrm{EC} \\
(\% \\
\text { RANO) }\end{array}$ & $\begin{array}{c}\mathrm{M} \\
\text { response } \\
\text { to } \mathrm{EC} \\
(\% \\
\text { RANO) }\end{array}$ & $\begin{array}{l}\text { Global } \\
\text { Response } \\
\text { to EC }\end{array}$ & $\begin{array}{c}\text { PNET HR+5 } \\
\text { strategy } \\
\text { continuation }\end{array}$ & $\begin{array}{c}\text { Post- } \\
\text { induction } \\
\text { strategy }\end{array}$ & $\begin{array}{c}\text { Relaps } \\
\text { type }\end{array}$ \\
\hline 2 & $\begin{array}{c}\mathrm{F} \\
9.7\end{array}$ & Biopsy & CMB & 4 & Yes & M3 & - & - & $\begin{array}{c}\text { SD } \\
(-16 \%)\end{array}$ & $\begin{array}{c}\text { No } \\
\text { change }\end{array}$ & SD & No & $\begin{array}{l}\text { 1-surgery } \\
\text { 2-RT } \\
\text { 3-St Jude } \\
\text { HDCT }\end{array}$ & $\overline{\text { Distan } 1}$ \\
\hline 4 & $\begin{array}{c}\mathrm{M} \\
14.7\end{array}$ & Total & CMB & 3 & No & M2 & + & & & $\begin{array}{c}\text { No } \\
\text { change }\end{array}$ & SD & Yes & $\begin{array}{l}\text { 1-HD-TTP } \\
\text { (1) } \\
\text { 2-RT 3- } \\
\text { Temodal } \\
\end{array}$ & Distan 1 \\
\hline 5 & $\begin{array}{c}\mathrm{M} \\
7.3\end{array}$ & Biopsy & CMB & 4 & No & M3 & + & + & $\begin{array}{c}\text { SD } \\
(-25 \%)\end{array}$ & Decrease & SD & Yes & $\begin{array}{l}\text { 1-surgery } \\
\text { 2-HD-TTP } \\
\text { (2) } \\
\text { 3-RT 4- } \\
\text { Temodal } \\
\end{array}$ & \\
\hline 6 & $\begin{array}{c}\mathrm{F} \\
10.3\end{array}$ & Subtotal & CMB & 4 & No & M2 & - & - & $\begin{array}{c}\text { No } \\
\text { change }\end{array}$ & $\begin{array}{c}\text { No } \\
\text { change }\end{array}$ & SD & No & $\begin{array}{l}\text { 1-surgery; } \\
\text { 2-RT; } \\
\text { 3-St Jude } \\
\text { HDCT } \\
\end{array}$ & $\begin{array}{c}\text { Local } \\
\text { and } \\
\text { distant }\end{array}$ \\
\hline 7 & $\begin{array}{c}\mathrm{F} \\
13.5\end{array}$ & Biopsy & CMB & 4 & No & M2 & - & & $\begin{array}{c}\text { SD } \\
(-10 \%)\end{array}$ & & SD & No & $\begin{array}{l}\text { 1-surgery; } \\
\text { 2-RT; } \\
\text { 3-St Jude } \\
\text { HDCT } \\
\end{array}$ & \\
\hline 8 & $\begin{array}{c}\mathrm{M} \\
2.0\end{array}$ & Subtotal & CMB & 3 & No & M1 & + & + & & & $\begin{array}{l}\text { SD-CSF- } \\
\text { only }\end{array}$ & Yes & $\begin{array}{l}\text { 1- EDX } \\
\text { 2-HD-TTP } \\
\text { (2) } \\
\text { 3-RT 4- } \\
\text { Temodal }\end{array}$ & \\
\hline 9 & $\begin{array}{c}\mathrm{F} \\
5.9\end{array}$ & Biopsy & CMB & - & No & M3 & + & + & $\begin{array}{c}\text { No } \\
\text { change }\end{array}$ & $\begin{array}{c}\text { No } \\
\text { change }\end{array}$ & SD & No & $\begin{array}{l}\text { 1-surgery; } \\
\text { 2-EDX } \\
\text { 3-RT 4-St } \\
\text { Jude HDCT }\end{array}$ & Distan1 \\
\hline 17 & $\begin{array}{c}\mathrm{M} \\
2.6\end{array}$ & Total & NOS & 3 & Yes & M3 & + & + & & $\begin{array}{c}\text { No } \\
\text { change }\end{array}$ & SD & Yes & $\begin{array}{l}\text { 1-HD-TTP } \\
\text { (1) } \\
\text { 2-Totem }\end{array}$ & Distant \\
\hline 18 & $\begin{array}{c}\mathrm{M} \\
4.8\end{array}$ & Total & CMB & 3 & No & M2 & - & - & & $\begin{array}{c}\text { No } \\
\text { change }\end{array}$ & SD & Yes & $\begin{array}{l}\text { 1-HD-TTP } \\
(2) \\
\text { 2-RT 3- } \\
\text { Temodal } \\
\end{array}$ & \\
\hline 21 & $\begin{array}{c}\mathrm{M} \\
5.3\end{array}$ & $\begin{array}{c}\text { Partial } \\
\text { (non } \\
\text { evaluable) }\end{array}$ & CMB & 4 & No & M3 & - & - & & $\begin{array}{c}\text { No } \\
\text { change }\end{array}$ & SD & No & $\begin{array}{l}\text { 1-Totem } \\
2 \text {-RT 3- } \\
\text { Temodal }\end{array}$ & Distan 1 \\
\hline 22 & $\begin{array}{c}\mathrm{F} \\
9.9\end{array}$ & $\begin{array}{c}\text { Partial } \\
(\mathrm{R}+)\end{array}$ & CMB & 4 & No & M3 & + & + & SD & $\begin{array}{c}\text { No } \\
\text { change }\end{array}$ & SD & No & $\begin{array}{l}\text { 1-Totem } \\
2 \text {-RT 3- } \\
\text { Temodal }\end{array}$ & $\begin{array}{c}\text { Distan } 1 \\
+ \text { CSF }\end{array}$ \\
\hline 23 & $\begin{array}{c}\mathrm{M} \\
5.9\end{array}$ & $\begin{array}{c}\text { Partial } \\
\text { (R-) }\end{array}$ & CMB & 4 & No & M3 & - & & & $\begin{array}{c}\text { No } \\
\text { change }\end{array}$ & SD & Yes & $\begin{array}{l}\text { 1-HD-TTP } \\
\text { (1) } \\
\text { 2-surgery } \\
3 \text {-RT } \\
\end{array}$ & \\
\hline 24 & $\begin{array}{c}\mathrm{M} \\
5.8\end{array}$ & Total & LCA & 3 & Yes & M2 & + & + & & Decrease & $\begin{array}{l}\text { SD-CSF- } \\
\text { only }\end{array}$ & Yes & $\begin{array}{l}\text { 1-HD-TTP } \\
(2) \\
2-\mathrm{RT}\end{array}$ & \\
\hline 26 & $\begin{array}{c}\mathrm{M} \\
7.5\end{array}$ & $\begin{array}{c}\text { Partial } \\
\text { (R-) }\end{array}$ & CMB & 4 & No & M2 & - & & $\begin{array}{c}\text { SD } \\
(-16 \%)\end{array}$ & $\begin{array}{c}\text { SD } \\
(-30 \%)\end{array}$ & SD & Yes & $\begin{array}{l}\text { 1-HD-TTP } \\
(2) \\
\text { 2-RT 3- } \\
\text { Temodal }\end{array}$ & \\
\hline 35 & $\begin{array}{c}\mathrm{F} \\
12.2\end{array}$ & Biopsy & CMB & & No & M3 & & & $\begin{array}{c}\text { SD } \\
(-20 \%)\end{array}$ & $\begin{array}{c}\text { No } \\
\text { change }\end{array}$ & SD & No & $\begin{array}{l}\text { 1-surgery- } \\
\text { 2-Temiri } \\
\text { 3-RT 4- } \\
\text { Temiri } \\
\end{array}$ & Distan 1 \\
\hline 36 & $\begin{array}{c}\mathrm{M} \\
10.9\end{array}$ & Biopsy & NOS & & No & M3 & - & & $\begin{array}{c}\text { SD } \\
(-0 \%)\end{array}$ & $\begin{array}{c}\text { No } \\
\text { change }\end{array}$ & SD & No & $\begin{array}{l}\text { 1-Temiri -2 } \\
\text { RT } \\
\text { 3-Temiri }\end{array}$ & - Distan \\
\hline 37 & $\begin{array}{c}\mathrm{F} \\
5.7\end{array}$ & $\begin{array}{c}\text { Partial } \\
(\mathrm{R}+)\end{array}$ & LCA & 3 & Yes & M3 & - & & $\begin{array}{c}\text { Non } \\
\text { evaluable }\end{array}$ & $\begin{array}{c}\text { SD } \\
(-13 \%)\end{array}$ & SD & No & $\begin{array}{l}\text { 1-Temiri } \\
\text { 2-RT 3- } \\
\text { Temiri }\end{array}$ & Distan 1 \\
\hline 38 & $\begin{array}{c}\mathrm{M} \\
9.0\end{array}$ & $\begin{array}{c}\text { Partial } \\
(\mathrm{R}+)\end{array}$ & CMB & 3 & No & M3 & + & + & $\begin{array}{c}\text { SD } \\
(-22 \%)\end{array}$ & Decrease & SD & No & $\begin{array}{l}\text { 1-Totem 2- } \\
\text { surgery } \\
3 \text {-RT 4-St } \\
\text { Jude HDCT } \\
\end{array}$ & Distan 1 \\
\hline 40 & $\begin{array}{c}\mathrm{M} \\
6.8\end{array}$ & Subtotal & CMB & & No & M3 & + & - & & $\begin{array}{c}\text { No } \\
\text { change }\end{array}$ & SD & No & $\begin{array}{l}\text { 1-Totem } \\
\text { 2-RT 3-St } \\
\text { Jude HDCT }\end{array}$ & $\begin{array}{c}\text { Local } \\
\text { and } \\
\text { distant }\end{array}$ \\
\hline 43 & $\begin{array}{c}M \\
9.8\end{array}$ & $\begin{array}{c}\text { Partial } \\
(\mathrm{R}+)\end{array}$ & CMB & & No & M2 & + & & $\begin{array}{c}\text { Non } \\
\text { evaluable }\end{array}$ & $\begin{array}{c}\text { No } \\
\text { change }\end{array}$ & SD & No & 1-Temiri- & $\begin{array}{l}\text { Local } \\
\text { and }\end{array}$ \\
\hline
\end{tabular}


2-RT 3- distant Totem

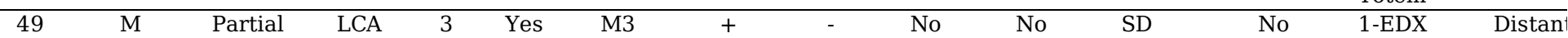
$2.6 \quad(\mathrm{R}+) \quad$ change change

\begin{tabular}{|c|c|c|c|c|c|c|c|c|c|c|c|c|c|c|}
\hline Num & $\begin{array}{l}\text { Gender/ } \\
\text { Age (y) }\end{array}$ & $\begin{array}{c}\text { Initial } \\
\text { Surgery } \\
(\mathbb{R} . \\
\text { status) }\end{array}$ & Histology & $\begin{array}{l}\text { MB } \\
\text { group }\end{array}$ & $\begin{array}{l}\text { MYCA } \\
\text { MYCNA }\end{array}$ & Chang & $\begin{array}{l}\text { Baseline } \\
\text { CSF }\end{array}$ & $\begin{array}{l}\text { Post- } \\
\text { EC } \\
\text { CSF }\end{array}$ & $\begin{array}{c}\text { PT } \\
\text { response } \\
\text { to } \mathrm{EC} \\
(\% \\
\text { RANO) }\end{array}$ & $\begin{array}{c}\mathrm{M} \\
\text { response } \\
\text { to } \mathrm{EC} \\
(\% \\
\text { RANO) }\end{array}$ & $\begin{array}{l}\text { Global } \\
\text { Response } \\
\text { to EC }\end{array}$ & $\begin{array}{l}\text { PNET HR+5 } \\
\text { strategy } \\
\text { continuation }\end{array}$ & $\begin{array}{c}\text { Post- } \\
\text { induction } \\
\text { strategy }\end{array}$ & $\begin{array}{r}\text { Relap: } \\
\text { type }\end{array}$ \\
\hline 19 & $\begin{array}{c}\mathrm{M} \\
18.1\end{array}$ & $\begin{array}{c}\text { Partial } \\
(\mathrm{R}+)\end{array}$ & CMB & 4 & No & M3 & + & + & $\begin{array}{c}\text { PR } \\
(-61 \%)\end{array}$ & Decrease & $\begin{array}{l}\text { SD-CSF- } \\
\text { only }\end{array}$ & Yes & $\begin{array}{l}\text { 1-HD-TTP } \\
(2) \\
2-\mathrm{RT}\end{array}$ & \\
\hline 25 & $\begin{array}{c}\mathrm{M} \\
8.8\end{array}$ & $\begin{array}{c}\text { Partial } \\
(\mathrm{R}+)\end{array}$ & $\overline{D M B}$ & 4 & No & M2 & - & & $\mathrm{SD}(-13 \%)$ & $\begin{array}{c}\mathrm{SD} \\
(+8 \%)\end{array}$ & SD & Yes & $\begin{array}{l}\text { 1-HD-TTP } \\
\text { (2) } \\
\text { 2-RT 3- } \\
\text { Temodal }\end{array}$ & \\
\hline 27 & $\begin{array}{c}\mathrm{F} \\
11.5\end{array}$ & Total & CMB & 4 & No & M3 & - & & & $\begin{array}{c}\text { No } \\
\text { change }\end{array}$ & SD & Yes & $\begin{array}{l}\text { 1-HD-TTP } \\
(2) \\
2-\mathrm{RT}\end{array}$ & \\
\hline 31 & $\begin{array}{c}\mathrm{M} \\
18.6\end{array}$ & Biopsy & CMB & & No & M2 & - & & $\begin{array}{c}\text { SD } \\
(-14 \%)\end{array}$ & $\begin{array}{c}\text { No } \\
\text { change }\end{array}$ & SD & Yes & $\begin{array}{l}\text { 1-surgery } \\
\text { 2-HD-TTP } \\
(2) \\
\text { 3-RT 4- } \\
\text { Temodal }\end{array}$ & $\overline{\text { Distar }}$ \\
\hline 33 & $\begin{array}{c}\mathrm{M} \\
5.3\end{array}$ & Total & CMB & 3 & No & M3 & + & + & & $\begin{array}{c}\text { No } \\
\text { change }\end{array}$ & SD & Yes & $\begin{array}{l}\text { 1-HD-TTP(1) } \\
\text { 2-Temiri- } \\
\text { 3-RT 4-Other } \\
\text { Maintenance }\end{array}$ & 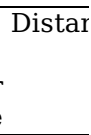 \\
\hline 50 & $\begin{array}{c}\mathrm{M} \\
5.0\end{array}$ & $\begin{array}{c}\text { Partial } \\
(\mathrm{R}+)\end{array}$ & CMB & 4 & Yes & M3 & & & $\begin{array}{c}\text { SD } \\
(-42 \%)\end{array}$ & $\begin{array}{c}\text { SD } \\
(+21 \%)\end{array}$ & SD & Yes & $\begin{array}{l}\text { 1-HD-TTP } \\
\text { (2) } \\
\text { 2-RT 3- } \\
\text { Temodal }\end{array}$ & \\
\hline 51 & $\begin{array}{c}\mathrm{F} \\
12.2\end{array}$ & Total & CMB & 4 & No & M3 & - & & & $\begin{array}{c}\text { No } \\
\text { change }\end{array}$ & SD & Yes & $\begin{array}{l}\text { 1-HD-TTP } \\
(2) \\
\text { 2-RT 3- } \\
\text { Temodal }\end{array}$ & \\
\hline 52 & $\begin{array}{c}F \\
8.6\end{array}$ & Biopsy & CMB & 3 & No & M3 & - & & $\begin{array}{c}\text { SD } \\
(+11 \%)\end{array}$ & $\begin{array}{c}\text { SD } \\
(+1.5 \%)\end{array}$ & SD & Yes & $\begin{array}{l}\text { 1-surgery } \\
\text { 2-HD-TTP(2) } \\
\text { 3-RT }\end{array}$ & \\
\hline 53 & $\begin{array}{c}\mathrm{F} \\
13.3\end{array}$ & $\begin{array}{c}\text { Partial } \\
(\mathrm{R}+)\end{array}$ & CMB & 3 & No & M3 & + & + & $\begin{array}{c}\text { PR (> - } \\
50 \%)\end{array}$ & $\begin{array}{c}\text { No } \\
\text { change }\end{array}$ & SD & Yes & $\begin{array}{l}\text { 1-surgery } \\
\text { 2-HD-TTP } \\
\text { (2) } \\
\text { 3-RT 4- } \\
\text { Temodal }\end{array}$ & Distar \\
\hline 55 & $\begin{array}{c}\mathrm{F} \\
11.0\end{array}$ & $\begin{array}{c}\text { Partial } \\
(\mathrm{R}+)\end{array}$ & $\overline{D M B}$ & 4 & No & M3 & - & - & $\begin{array}{c}\text { SD } \\
(-15 \%)\end{array}$ & $\begin{array}{c}\text { No } \\
\text { change }\end{array}$ & SD & Yes & $\begin{array}{l}\text { 1-HD-TTP } \\
(2) \\
2-\mathrm{RT}\end{array}$ & \\
\hline 56 & $\begin{array}{c}\mathrm{M} \\
6.2\end{array}$ & Total & $\overline{\mathrm{DMB}}$ & 4 & No & M3 & - & - & & $\begin{array}{c}\text { No } \\
\text { change }\end{array}$ & SD & Yes & $\begin{array}{l}\text { 1-HD-TTP } \\
(2) \\
2-\mathrm{RT}\end{array}$ & \\
\hline 57 & $\begin{array}{c}\mathrm{F} \\
5.2\end{array}$ & Total & CMB & 4 & & M2 & - & & & $\begin{array}{c}\text { No } \\
\text { change }\end{array}$ & SD & Yes & $\begin{array}{l}\text { 1-HD-TTP } \\
\text { (2) } \\
\text { 2-RT 3- } \\
\text { Temodal }\end{array}$ & \\
\hline 58 & $\begin{array}{c}\mathrm{F} \\
5.0\end{array}$ & Total & LCA & 3 & No & M1 & + & + & & & $\begin{array}{l}\text { SD-CSF- } \\
\text { only }\end{array}$ & Yes & $\begin{array}{l}\text { 1-HD-TTP } \\
(2) \\
2-\mathrm{RT}\end{array}$ & \\
\hline 59 & $\begin{array}{c}\mathrm{M} \\
14.8\end{array}$ & Total & NOS & 4 & No & M3 & + & + & & $\begin{array}{c}\text { No } \\
\text { change }\end{array}$ & SD & Yes & $\begin{array}{l}\text { 1-HD-TTP } \\
\text { (2) } \\
\text { 2-RT 3- } \\
\text { Temodal }\end{array}$ & \\
\hline 60 & $\begin{array}{c}\mathrm{M} \\
5.3\end{array}$ & Total & CMB & 3 & No & M3 & - & & & $\begin{array}{c}\text { No } \\
\text { change }\end{array}$ & SD & Yes & $\begin{array}{l}\text { 1-HD-TTP } \\
\text { (1) } \\
\text { 2-RT 3- } \\
\text { Temodal }\end{array}$ & \\
\hline 61 & $\begin{array}{c}\mathrm{M} \\
7.3\end{array}$ & $\begin{array}{c}\text { Partial } \\
(\mathrm{R}+)\end{array}$ & CMB & 4 & No & M2 & - & - & $\begin{array}{c}\text { SD } \\
(+9 \%)\end{array}$ & $\begin{array}{c}\text { No } \\
\text { change }\end{array}$ & SD & Yes & $\begin{array}{l}\text { 1-HD-TTP } \\
\text { (2) } \\
\text { 2-RT 3- } \\
\text { Temodal } \\
\text { 4-surgery }\end{array}$ & \\
\hline
\end{tabular}




\begin{tabular}{|c|c|c|c|c|c|c|c|c|c|c|c|c|c|c|}
\hline $\begin{array}{l}\text { Num } \\
(\mathrm{NP} / \mathrm{P} \\
\text { status })\end{array}$ & $\begin{array}{l}\text { Gender/ } \\
\text { Age (y) }\end{array}$ & $\begin{array}{c}\text { Initial } \\
\text { Surgery } \\
(\mathbb{R} . \\
\text { status) }\end{array}$ & Histology & $\begin{array}{l}\text { MB } \\
\text { group }\end{array}$ & $\begin{array}{l}\text { MYCA } \\
\text { MYCNA }\end{array}$ & Chang & $\begin{array}{c}\text { Baseline } \\
\text { CSF }\end{array}$ & $\begin{array}{l}\text { Post- } \\
\text { EC } \\
\text { CSF }\end{array}$ & $\begin{array}{c}\text { PT } \\
\text { response } \\
\text { to } \mathrm{EC} \\
(\% \mathrm{RANO})\end{array}$ & $\begin{array}{c}\mathrm{M} \\
\text { response } \\
\text { to } \mathrm{EC} \\
(\% \\
\text { RANO) }\end{array}$ & $\begin{array}{l}\text { Global } \\
\text { Response } \\
\text { to EC }\end{array}$ & $\begin{array}{l}\text { PNET HR+5 } \\
\text { strategy } \\
\text { continuation }\end{array}$ & $\begin{array}{c}\text { Post- } \\
\text { induction } \\
\text { strategy }\end{array}$ & $\begin{array}{r}\text { Rel } \\
t\end{array}$ \\
\hline $\begin{array}{c}10 \\
\text { (NP) }\end{array}$ & $\begin{array}{c}\mathrm{M} \\
5.0\end{array}$ & Total & $\overline{\text { LCA }}$ & & Yes & M1 & + & + & & $\begin{array}{c}\text { New } \\
\text { lesions }\end{array}$ & PD & No & $\begin{array}{l}\text { 1-EDX } \\
\text { 2-RT } \\
\text { 3-Temodal }\end{array}$ & $\overline{\text { Dis }}$ \\
\hline $\begin{array}{c}15 \\
\text { (NP) }\end{array}$ & $\begin{array}{c}\mathrm{M} \\
6.7\end{array}$ & $\begin{array}{l}\text { Partial } \\
\text { (R-) }\end{array}$ & CMB & 4 & No & M3 & + & & No change & Increase & PD & No & $\begin{array}{l}\text { 1-RT } \\
\text { 2-Totem }\end{array}$ & $\overline{\text { Dis }}$ \\
\hline $\begin{array}{l}20 \\
(\mathrm{NP})\end{array}$ & $\begin{array}{c}\mathrm{M} \\
10.2\end{array}$ & $\begin{array}{c}\text { Partial } \\
(\mathrm{R}+)\end{array}$ & CMB & & No & M2 & - & + & $\begin{array}{c}\text { SD } \\
(-47 \%)\end{array}$ & Decrease & $\begin{array}{l}\text { PD-CSF- } \\
\text { only }\end{array}$ & No & $\begin{array}{l}\text { 1-RT } \\
\text { 2-Temodal }\end{array}$ & \\
\hline $\begin{array}{c}28 \\
(\mathrm{NP})\end{array}$ & $\begin{array}{c}\mathrm{F} \\
4.8\end{array}$ & Total & NOS & & Yes & M0 & - & + & & & $\begin{array}{l}\text { PD-CSF- } \\
\text { only }\end{array}$ & Yes & $\begin{array}{l}\text { 1-HD- } \\
\text { TTP(2) } \\
\text { 2-RT } \\
\text { 3-Temodal }\end{array}$ & $\begin{array}{r}1 \\
\text { (be } \\
\text { bc } \\
\text { tur }\end{array}$ \\
\hline $\begin{array}{c}29 \\
\text { (NP) }\end{array}$ & $\begin{array}{c}\mathrm{M} \\
3.0\end{array}$ & $\begin{array}{c}\text { Partial } \\
(\mathrm{R}+)\end{array}$ & LCA & 3 & No & M3 & + & - & $\begin{array}{c}\text { PR } \\
(-66 \%)\end{array}$ & $\begin{array}{c}\text { PD } \\
(+50 \%)\end{array}$ & PD & No & 1-Totem & $\overline{\text { Dis }}$ \\
\hline $\begin{array}{c}30 \\
\text { (NP) }\end{array}$ & $\begin{array}{c}\mathrm{M} \\
6.5\end{array}$ & Total & $\overline{\text { LCA }}$ & & Yes & M3 & + & + & & Increase & PD & No & 1-Temiri & $\overline{\text { Dis }}$ \\
\hline $\begin{array}{c}39 \\
\text { (NP) }\end{array}$ & $\begin{array}{c}\mathrm{F} \\
9.6\end{array}$ & Biopsy & $\overline{\text { LCA }}$ & 3 & Yes & M3 & - & + & $\begin{array}{c}\text { Non } \\
\text { evaluable }\end{array}$ & Increase & PD & No & 1-Totem & $\overline{\text { Dis }}$ \\
\hline $\begin{array}{c}42 \\
\text { (NP) }\end{array}$ & $\begin{array}{c}\mathrm{M} \\
5.8\end{array}$ & Biopsy & CMB & & No & M2 & + & + & $\begin{array}{c}\text { SD } \\
(-20 \%)\end{array}$ & Increase & PD & Yes & $\begin{array}{l}\text { 1-surgery } \\
\text { 2-HD- } \\
\text { TTP(1) }\end{array}$ & $\overline{\text { Dis }}$ \\
\hline $\begin{array}{c}45 \\
\text { (NP) }\end{array}$ & $\begin{array}{c}\mathrm{M} \\
17.5\end{array}$ & $\begin{array}{c}\text { Partial } \\
(\mathrm{R}+)\end{array}$ & CMB & 3 & No & M0 & - & - & $\begin{array}{c}\text { SD } \\
(-34 \%)\end{array}$ & $\begin{array}{c}\text { New } \\
\text { lesions }\end{array}$ & $\overline{P D}$ & No & 1-Totem & $\begin{array}{r}\mathrm{Lc} \\
\mathrm{a} \\
\text { dis }\end{array}$ \\
\hline $\begin{array}{l}41 \\
\text { (P) }\end{array}$ & $\begin{array}{c}\mathrm{M} \\
9.7\end{array}$ & Subtotal & LCA & 3 & No & M0 & - & + & $\begin{array}{c}\text { PD } \\
(+75 \%)\end{array}$ & $\begin{array}{c}\text { New } \\
\text { lesions }\end{array}$ & PD & No & 1-Temiri & $\begin{array}{r}\mathrm{Lc} \\
\mathrm{a} \\
\text { dis }\end{array}$ \\
\hline $\begin{array}{l}54 \\
\text { (P) }\end{array}$ & $\begin{array}{c}\mathrm{M} \\
5.6\end{array}$ & Subtotal & $\overline{\mathrm{CMB}}$ & 3 & No & M3 & - & - & Increase & Increase & PD & No & None & $\begin{array}{r}\mathrm{Lc} \\
\mathrm{a} \\
\text { dis }\end{array}$ \\
\hline $\begin{array}{l}62 \\
\text { (P) }\end{array}$ & $\begin{array}{c}\mathrm{M} \\
15.9\end{array}$ & Total & $\overline{L C A}$ & 2 & Yes & M3 & + & + & & Increase & PD & Yes & $\begin{array}{l}\text { 1-HD-TTP } \\
\text { (2) }\end{array}$ & $\begin{array}{r}\text { Dis } \\
\mathrm{a} \\
\mathrm{C}\end{array}$ \\
\hline
\end{tabular}

Empty boxes refer to analyses (CSF, molecular grouping) "not done" or "no visible tumor available for response assessment" of the induction therapy.

For the patients who underwent partial resection: R+: postoperative residue $1.5 \mathrm{~cm}^{2}$; R-: postoperative residue $<1.5 \mathrm{~cm}$;

-: negative cerebrospinal fluid cytology; +: positive cerebrospinal fluid cytology

(+ \%): percentage increase for measurable lesion according to RANO;

(- \%): percentage decrease for measurable lesion according to RANO

$(N P)$ : non-protocolar patient $(P)=$ protocolar patient

CSF: cerebrospinal fluid

PT: primitive tumor; $M=$ metastasis; $E C=$ etoposide carboplatin; $R T$ : radiotherapy;

HD-TTP $(X)$ : high-dose thiotepa (number of courses); St Jude HDCT: modified Saint Jude strategy

DOD: dead of the disease; AWD: alive with the disease CCR: continuing complete remission

Table 3 Univariate and multivariate analysis for outcomes among the patients with post induction stable disease.

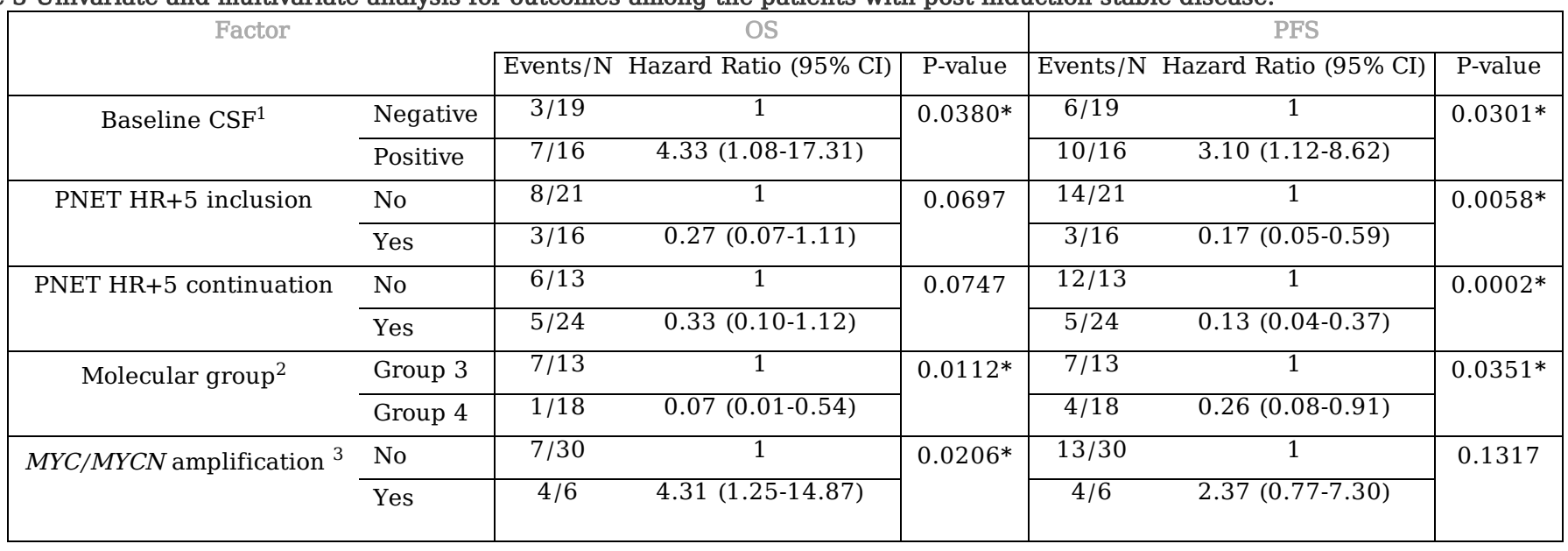




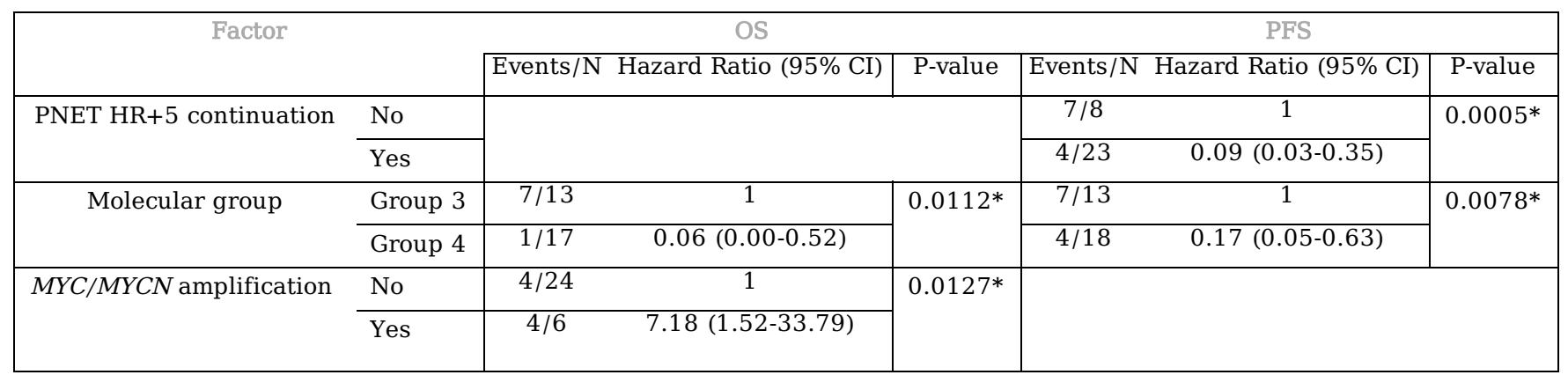

3a. Univariate Cox regression model. 3b. Final multivariate Cox model results after backward procedure. Information missing in ${ }^{\mathrm{a}} 1$ patient, ${ }^{\mathrm{b}} 6$ patients, and ${ }^{\mathrm{c}} 1$ patient.

CSF: cerebrospinal fluid, $N=$ number of patients with available results for the studied factor

\section{Figures}

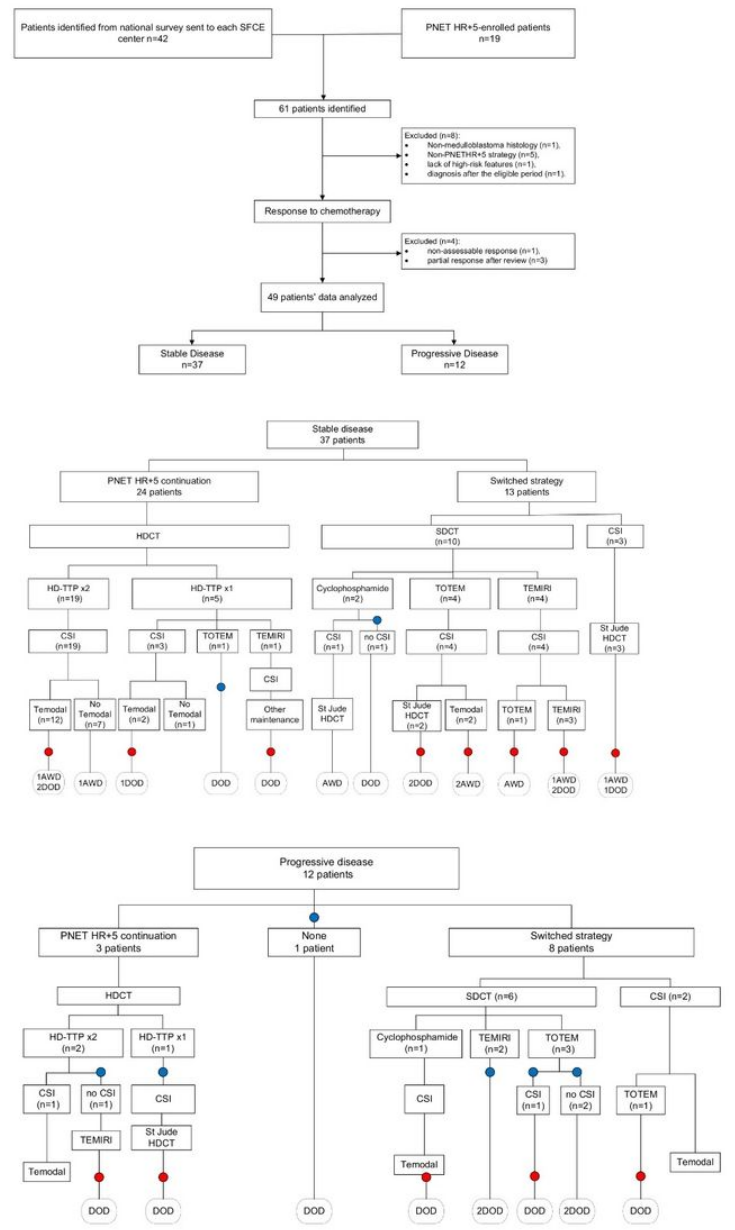

Figure 1

Flowcharts of the study. 1a: Study outline-Entire population; 1b: Stable disease group; 1c: Progressive disease group Early progression after a second-line strategy post-EC is represented by blue circles while the later events (relapses or progression after achieving the full treatment strategy) are indicated with red circles. Other maintenance in Flowchart $1 \mathrm{~b}$ refers to the temozolomide-based metronomic maintenance therapy described by $\mathrm{CHOI}$ et al., 2008 [14]. HD-

Thiotepa: High-dose thiotepa x number of courses, CSI: craniospinal irradiation, HDCT: high-dose chemotherapy; SDCT: Standard-dose chemotherapy; St Jude HDCT: Modified Saint Jude strategy X DOD: number of dead of the disease; X AWD: number of patients alive with the disease 

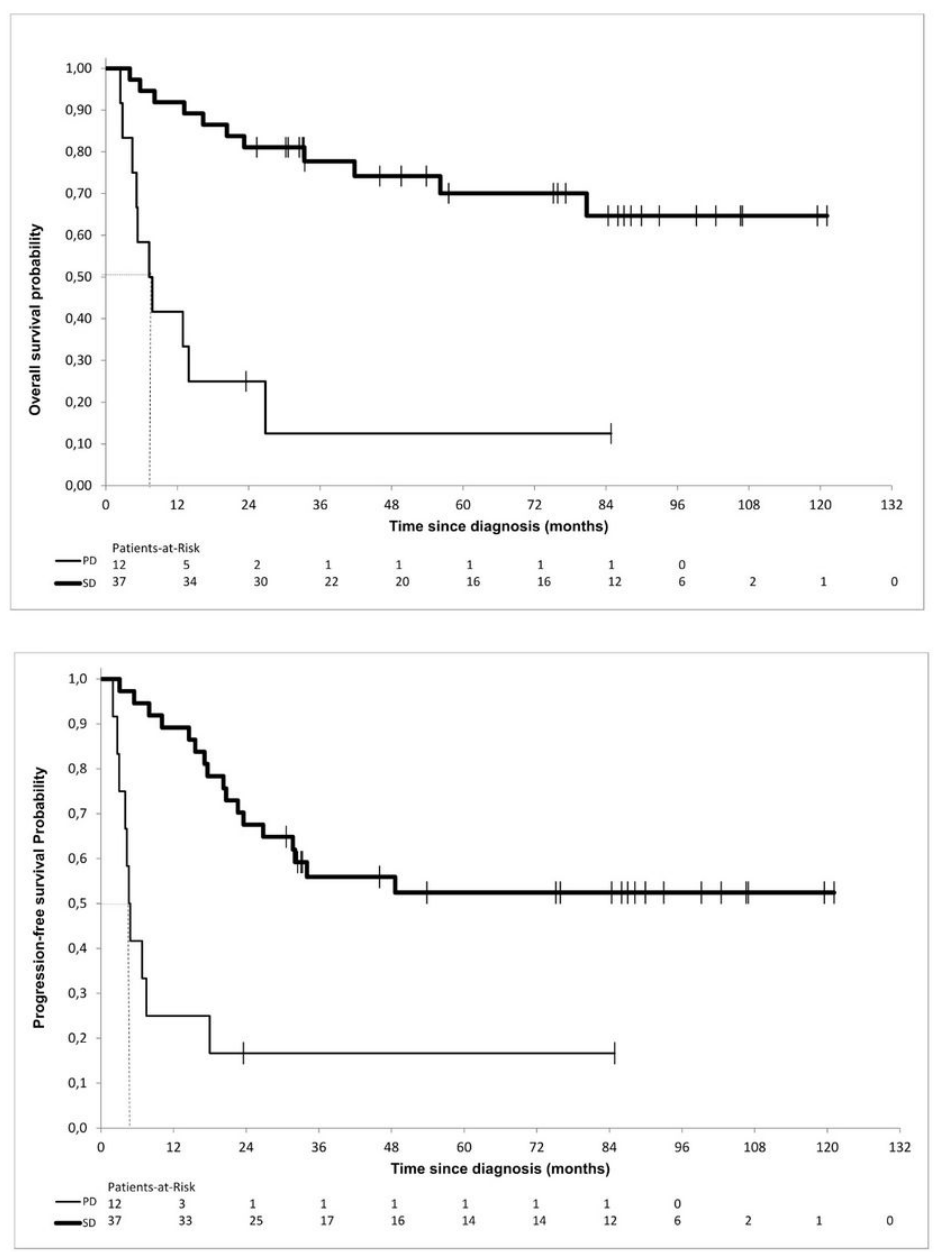

Figure 2

OS and PFS according to the type of post-induction response. 2a. Probability of overall survival (Kaplan-Meier, log-rank). 2b. Probability of progression-free survival (Kaplan-Meier, log-rank). Thin line: PD; Thick line: SD. 

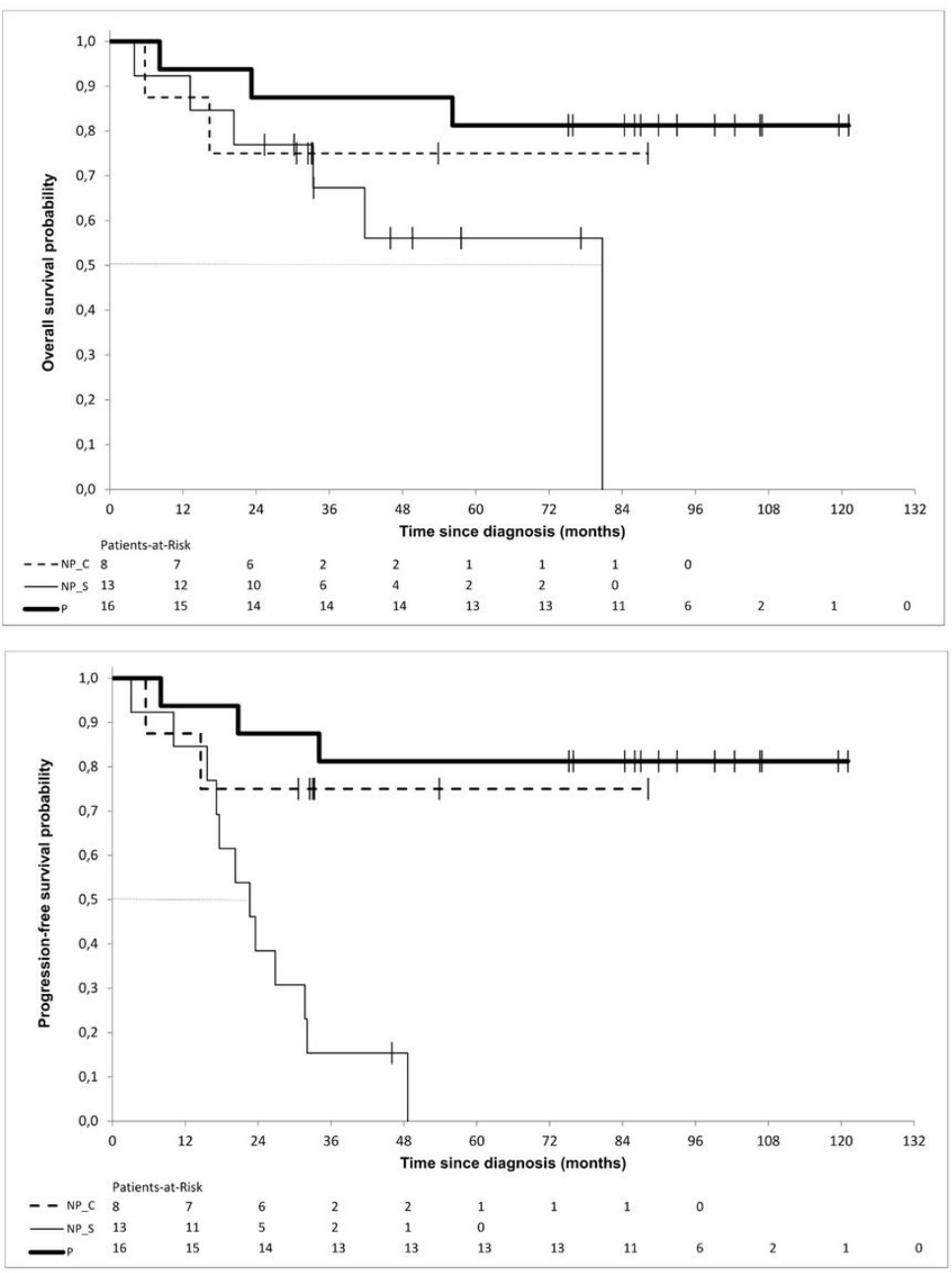

\section{Figure 3}

OS and PFS of patients with SD by PNET HR+5 inclusion and continuation. 3a. Probability of overall survival (Kaplan-Meier, log-rank). 3b. Probability of progression free survival (Kaplan-Meier, log-rank). Thick line: protocolar patients with PNET HR+5 continuation (P); Dashed line: non-protocolar patients with PNET HR+5 continuation (NP_ C); Thin line: non-protocolar patients with switched therapy (NP_S) 